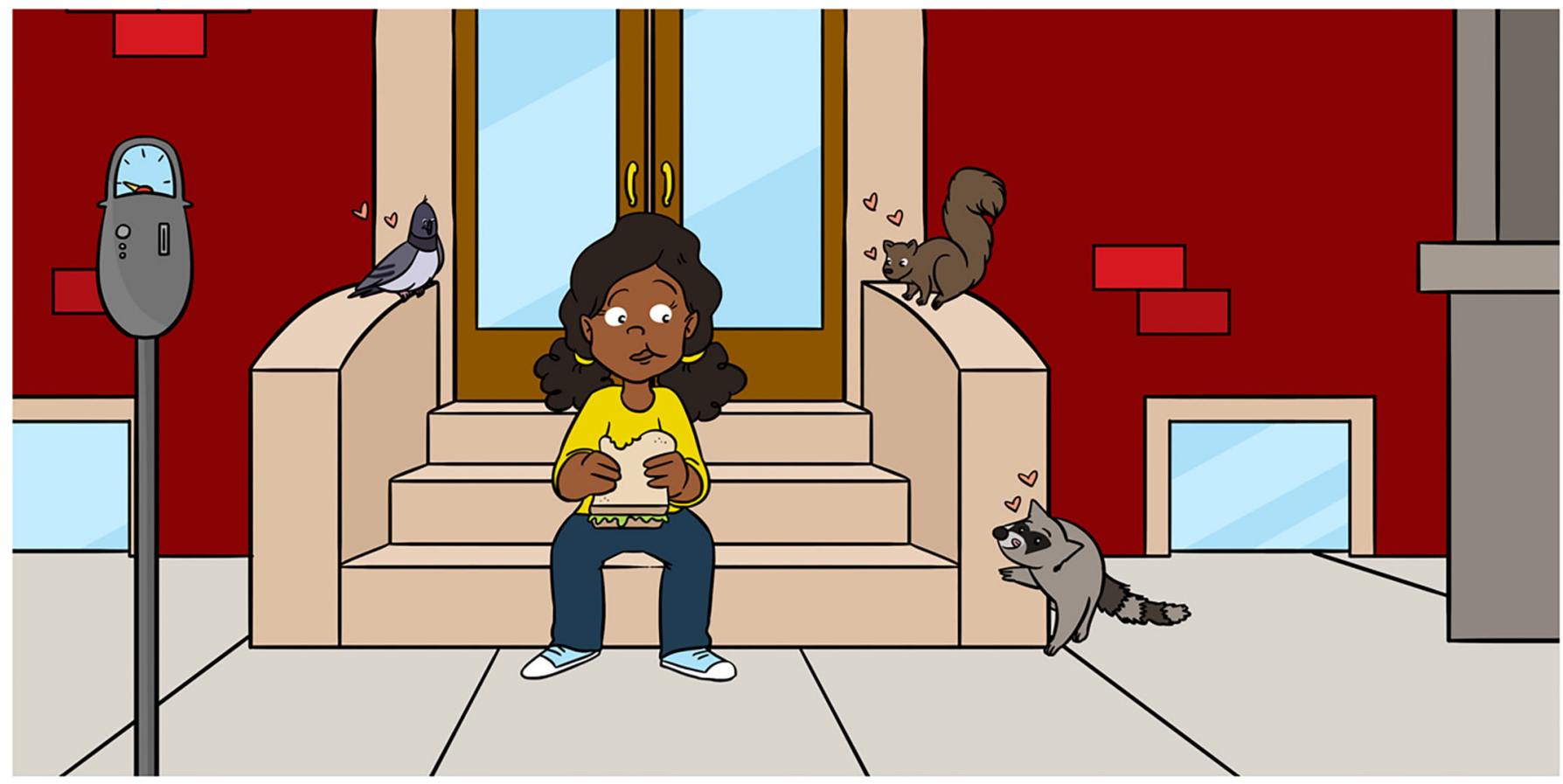

\title{
WHY DO ANIMALS LIVE IN CITIES?
}

Seth B. Magle*, Cria A. M. Kay, Jacqueline Buckley, Kimberly R. Fake, Mason Fidino, Elizabeth W. Lehrer and Maureen H. Murray

Urban Wildife Institute, Lincoln Park Zoo, Chicago, IL, United States

YOUNG REVIEWER:

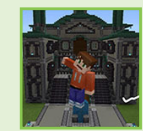

LANGSTON

AGE: 12
Cities are intended to be places for people to live, but some animals survive and even thrive in cities. Animals that are smaller, have more general diets, and are more intelligent or adaptable are especially good at city life. Many of these wildlife species have learned special behaviors to help them survive in urban areas. Scientists use many tools to study these animals because understanding wildlife in cities can help people learn to live with them. There are many things you can do to help scientists learn more about the animals you see every day and make your neighborhood a better place for wild animals.

\section{WILD CITIES}

It makes sense that people live in cities. Cities have schools, stores, and lots of places to live in. But why would wild animals (often called wildlife) want to live in a city? We built cities for humans, not for animals, but animals found them anyway! Now it seems that more and more animals are showing up in places that we would not expect them to. But why? Cities can be challenging places for wildlife. Cities 
Figure 1

Examples of common urban wildlife. (a) Red-winged blackbird, Agelaius phoeniceus.

(b) Coyote, Canis latrans. (c) Silver-haired bat, Lasionycteris noctivagans. (d) Monarch butterfly Danaus plexippus [Photo credits (a) Danielle Eastin, (b) Julia Fuller, (c) Induk Kim, and (d) AZA SAFE, Blank Park Zoo].

\section{HABITAT}

The space where animals can find food, shelter,

mates-their home.

\section{URBAN WILDLIFE}

Wild animals that live in cities.

\section{GENERALISTS}

Species that can eat many different types of food.

\section{SPECIALISTS}

Species that focus on eating only one, or a few, kinds of food.
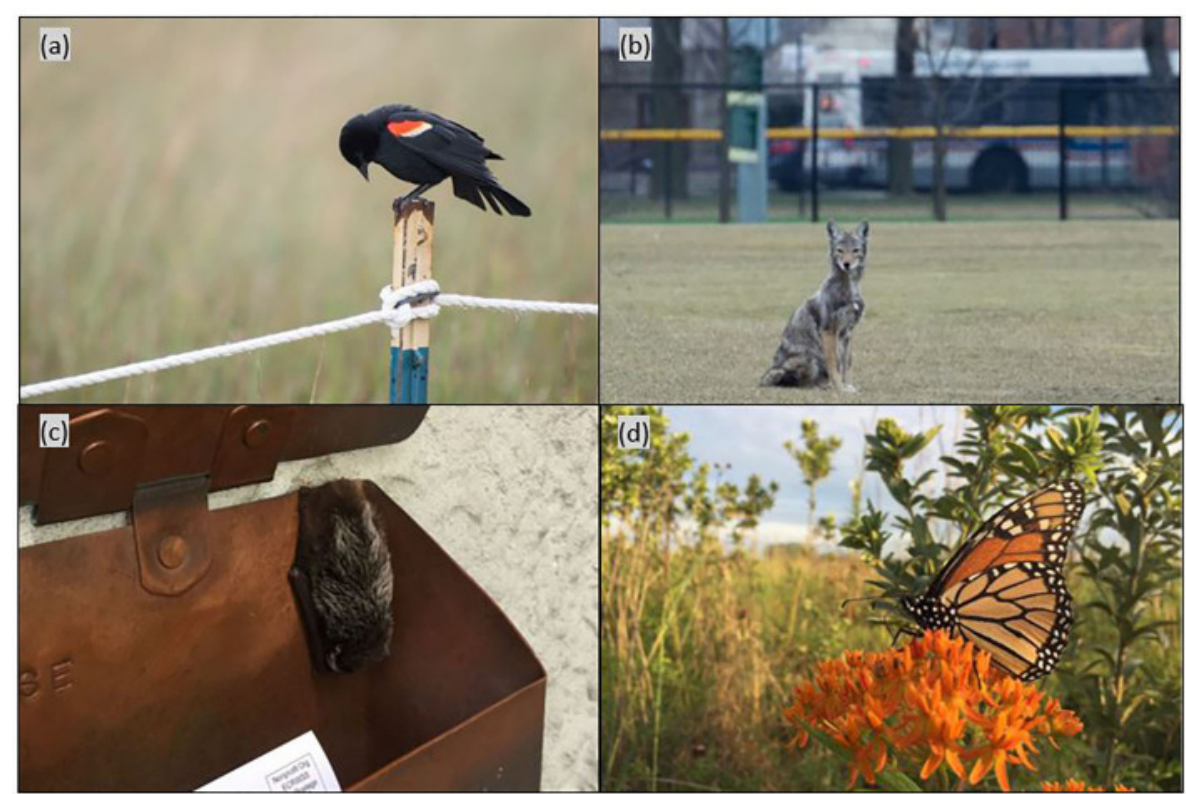

Figure 1

have a lot of buildings, cars, and roads, and less space where animals can find shelter and food. We call the places animals live their habitat, and buildings, roads, and traffic can make it hard for animals to move around to find that habitat.

But scientists have learned that some species do better in cities than they do in habitats outside of cities. It turns out cities can provide a lot of good food, shelter, and protection for some wildlife. These animals live longer, have more babies, and get more to eat than they would in other habitats. Peregrine falcons, for example, use tall city buildings for nesting sites, man-made lighting to hunt for prey at night, and warm air currents created when the sun beats down on city surfaces to soar with less effort [1]. If you think about it, you probably already know a lot of wildlife species that live successfully in cities. Have you seen squirrels in your neighborhood? Pigeons? Rabbits? Maybe a raccoon? These are all examples of animals that can live in cities, which scientists call urban wildlife (Figure 1).

\section{WHAT SORTS OF ANIMALS DO WELL IN CITIES?}

Some animals adjust well to city life, and some do not. For example, squirrels do amazingly well living in cities, while wolves have never seemed to get the hang of it. While a lot is still unknown, there are some patterns in the kinds of wildlife that thrive in cities. Usually, animals that eat a lot of different things, which biologists call generalists, do much better in cities than specialists, which need to eat one specific kind of food. Cities create new places for wildlife to find food, like in trash, gardens, and grassy lawns. An animal that only eats one type of food may have trouble finding it in a big city, 
Figure 2

Methods

for monitoring urban wildlife. (a) Telemetry tracking allows scientists to follow animal movement using devices that send signals back to the researchers. (b) Camera traps take photos of animals that pass in front of the camera. (C) Bat monitors collect sound recordings of bat calls. (d) Point counts help scientists record all the birds they see or hear at a fixed location during a specific period of time [Photo credits

(a), Sharon Deem, $(b, c)$ Julia Fuller, and (d)

Drew Mallinak].
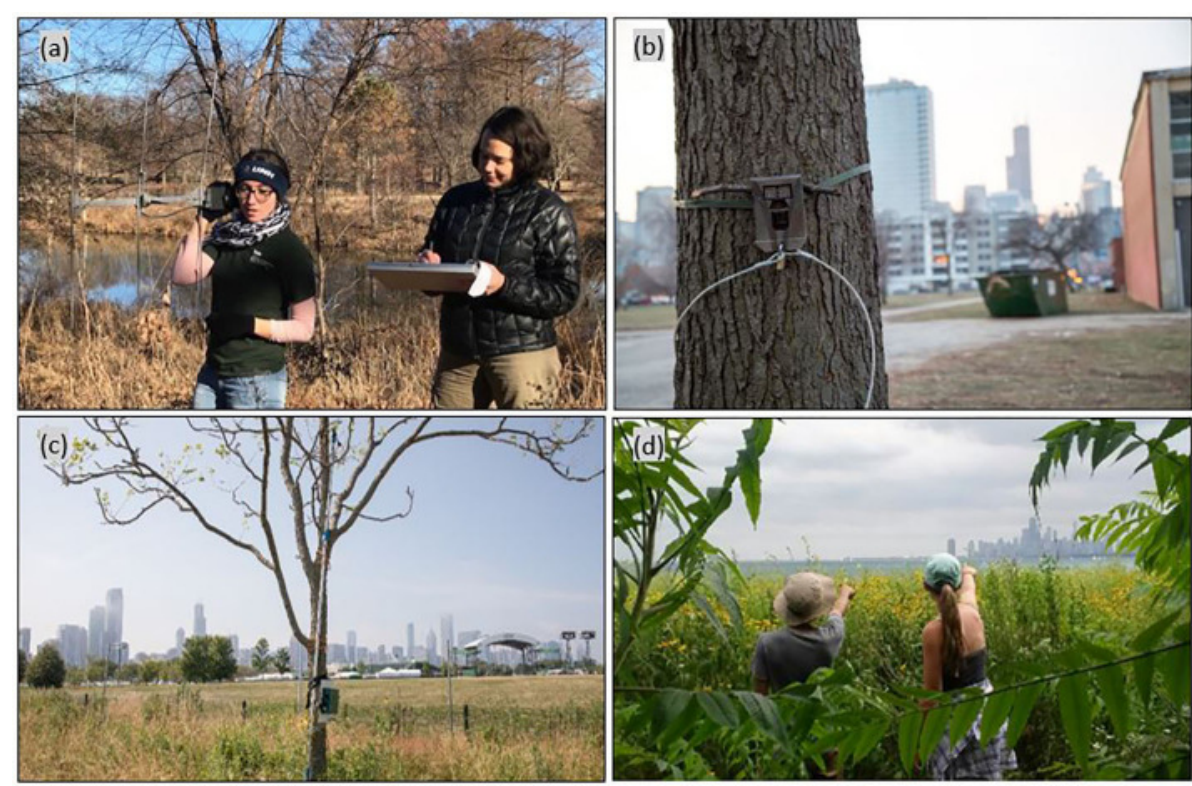

Figure 2

like black-footed ferrets that only eat prairie dogs. But an animal that eats all sorts of things can do much better. Coyotes in cities eat many different kinds of meat-mice, rats, squirrels, rabbits, and deer, but they also eat fruit. Raccoons eat plants, meat, seeds, fruit, and human garbage-anything they can find! That is one reason why raccoons live in cities all across North America, while black-footed ferrets do not.

Smaller animals, like mice, are also more likely to live in cities than bigger animals, like moose. That is because bigger animals need a lot of room to roam, and a lot of food to eat. In cities, there is less space for wildlife. Some people think that animals that do well in cities might be generally smarter than the ones who do not, though more research is needed on this. Cities are always changing, and in some ways are more complicated than forests, or swamps, or other habitats. Cities have lots of new rules that animals must figure out because they have not adapted to buildings or garbage or traffic. For example, some animals have learned to change the time of day that they are awake to avoid people. Coyotes live in cities across North America and have learned to be active at night, when there are fewer cars [2]. That must take a lot of brainpower!

Many animals have even learned cool tricks to live in cities, and these behaviors help them find more food or mates, or avoid people. Some bird species, for example, have learned to sing at a higher pitch so other birds can hear them over city noise [3]. Other animals, like coyotes, deer, raccoons, and even mice use storm drains, which humans built to help water move underneath roads, to move around the city and avoid cars and people [4]. 


\section{TELEMETRY}

Methods used by scientists to study how animals move, by attaching devices to them that can be tracked and followed.

HUMAN-WILDLIFE CONFLICT

Problems that wildlife can cause for humans, including eating our gardens, hurting pets, or spreading diseases.

\section{ECOSYSTEM}

\section{SERVICES}

The benefits that nature and wildlife give to humans, including cleaning our air and water, giving people food, and improving people's health.
So, animals do interesting things to live in cities, but how do scientists study these animals and learn about their behaviors? To learn about where animals live, we use recording devices like cameras to spot animals, or microphones to record the sounds they make. To track how animals move around, we attach tracking equipment to them, which is a process called telemetry, so we can see exactly where the animals go. Scientists use many different tools to study what animals eat, how healthy they are, how they compete with each other, how many of them there are, and more (Figure 2).

\section{WHY DOES IT MATTER IF ANIMALS LIVE IN CITIES?}

You might think the animals in cities are not as important to understand as lions and pandas, but that is not true. Did you know most people in the world live in cities? That means that the wildlife most people will watch, hear, and interact with are urban wildlife. Connecting people to nature and wildlife is important. People feel better and are healthier when they have access to nature. Many of us like to watch animals in our neighborhoods. It brings us happiness to hear birds singing in our backyards, or even to hear a coyote howl from a nearby park. It reminds us that cities are wilder places than we thought. It reminds us that no matter where we live, we are part of nature.

Although nature is good for our health, sometimes animals can cause trouble for people. This is called human-wildlife conflict. Imagine the skunk that sprays your dog with that gross smell, or the rabbits that munch on your family's garden. People can accidentally hit animals with their cars, which is not only dangerous for the animals, but can also be dangerous for us if the animal is large, like a deer. When they feel threatened, some animals can even attack us or our pets, though this is very rare. With a better understanding, we can try to stop these conflicts from happening, which is another reason why scientists study urban wildlife.

Fortunately, it also turns out that animals do an incredible number of things that can help humans. Bats eat moths and mosquitoes that bother us. Bees, wasps, and other insects pollinate our gardens. Bigger predators like coyotes, foxes, and hawks eat mice and rats that eat our food and might carry diseases. Scientists call these helpful actions ecosystem services, and these services are critically important to our environment.

\section{CAN CITIES PROTECT WILDLIFE?}

You might have heard that a lot of wildlife is at risk of going extinct, and that is true. Humans are turning the planet into cities and farms, which does not leave many other places for most wildlife to live. But here is the reality: people need cities, and cities are going to keep 
getting bigger. So, what can we do to make our cities more welcoming to wildlife?

There are several things you can do to make your home or neighborhood more wildlife-friendly. At home, you can cover your trash carefully and avoid feeding wild animals. Trash is not good for animals and they get in trouble when they start rummaging around in it, so it is better for everyone if they eat more natural foods. Do you have a yard or balcony? See if you can plant some plants that are native to your area, that wildlife might like. For example, milkweed is a flower that is easy to grow and an important food source for monarch butterflies. When you see animals in a city, you can give them space and watch them from far away. You can also identify and learn more about them using apps like eBird, iNaturalist, or Project Feeder Watch. Most of these apps also share what you learn with scientists, so you will be helping with research on urban wildlife too! There might be organizations in your area, like nature centers, universities, or zoos, that work to make or improve habitats for wildlife or research them-maybe you can ask to volunteer!

Some scientists think another solution is to create cities that have more places for wildlife to live in. We could leave or build more natural spaces around our roads, houses, schools and workplaces, and we could also try some creative things like green roofs, which are roofs that have plants on them where birds and insects can live. If you put it all together, we could build wildlife-friendly cities, places built not just for people, but for wildlife too [5]. To do that, we need to know a lot more about why some wild animals survive in cities and some do not, what kind of habitats different species need, and how to prevent human-wildlife conflict. We still have a lot to learn.

Why do animals live in cities? Some live in cities because they have to, but more and more live in cities because they want to. In fact, if humans and wildlife are going to learn better ways to share the planet, cities might just hold the key.

\section{ACKNOWLEDGMENTS}

We thank E. Martell for help with this manuscript, and the young reviewers for their comments.

\section{REFERENCES}

1. DeCandido, R., and Allen, D. 2006. Nocturnal hunting by peregrine falcons at the empire state building, New York City. Wilson J. Ornithol. 118:53-8. doi: 10.1676/ 1559-4491(2006)118[0053:NHBPFA]2.0.CO;2

2. Murray, M., and St. Clair, C. 2015. Individual flexibility in nocturnal activity reduces risk of road mortality for an urban carnivore. Behav. Ecol. 26:1520-7. doi: 10.1093/beheco/arv102 
3. Slabbekoorn, H., and Peet, M. 2003. Birds sing at a higher pitch in urban noise. Nature 424:267. doi: 10.1038/424267a

4. Clevenger, A. P., Chruszcz, B., and Gunson, K. 2002. Drainage culverts as habitat linkages and factors affecting passage by mammals. J. Appl. Ecol. 38:1340-9. doi: 10.1046/j.0021-8901.2001.00678.x

5. Apfelbeck, B., Snep, R. P. H., Hauck, T. E., Ferguson, J., Holy, M., Jakoby, C., et al. 2020. Designing wildlife-inclusive cities that support human-animal co-existence. Landsc. Urban Plann. 200:103817. doi: 10.1016/j.landurbplan. 2020.103817

SUBMITTED: 27 May 2020; ACCEPTED: 08 February 2021; PUBLISHED ONLINE: 08 March 2021.

EDITED BY: Pedro Morais, University of Algarve, Portugal

CITATION: Magle SB, Kay CAM, Buckley J, Fake KR, Fidino M, Lehrer EW and Murray MH (2021) Why Do Animals Live in Cities? Front. Young Minds 9:566272. doi: $10.3389 /$ frym.2021.566272

CONFLICT OF INTEREST: The authors declare that the research was conducted in the absence of any commercial or financial relationships that could be construed as a potential conflict of interest.

COPYRIGHT @ 2021 Magle, Kay, Buckley, Fake, Fidino, Lehrer and Murray. This is an open-access article distributed under the terms of the Creative Commons Attribution License (CC BY). The use, distribution or reproduction in other forums is permitted, provided the original author(s) and the copyright owner(s) are credited and that the original publication in this journal is cited, in accordance with accepted academic practice. No use, distribution or reproduction is permitted which does not comply with these terms.

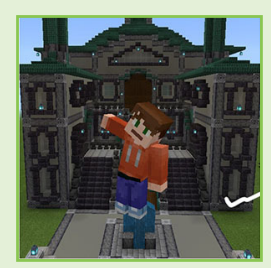

\section{YOUNG REVIEWER}

\section{LANGSTON, AGE: 12}

My name is Langston and I am 12 years old. Some of the things I like to do include playing sports and video games. My favorite subject is math. When I grow up I want to be an architect.

\section{AUTHORS}

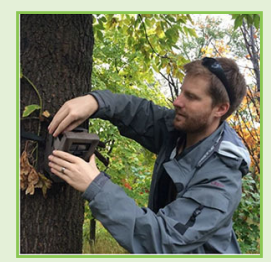

\section{SETH B. MAGLE}

I have been studying urban animals since I was 19 , when I started watching prairie dogs playing on the sidewalk across the street from my home. I am the Director of the Urban Wildlife Institute at the Lincoln Park Zoo and now I study urban animals ranging from coyotes to chickadees. My vision is to help create a world where cities are part of the solution to the extinction crisis. *smaglealpzoo.org 

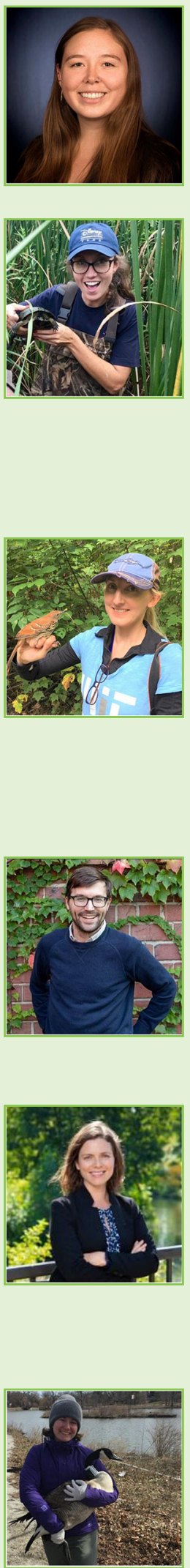

\section{CRIA A. M. KAY}

I am the Coordinator for the Urban Wildlife Information Network at the Lincoln Park Zoo in Chicago, Illinois. My research focuses on how wildlife adapts to urban environments and how collaboration between urban planning, architecture, and science can create more wildlife-friendly cities.

\section{JACQUELINE BUCKLEY}

Jacqueline got her master's degree in conservation medicine in 2019. In the past she has worked as a zookeeper for many years, with a wide range of animals like hyena, giraffe, maned wolves, African wild dogs, bats, and cows. She is currently a One Health research coordinator at the Lincoln Park Zoo. She has an interest in the connection between the health of animals, humans, and the environment. When Jackie is not at work, you can find her kayaking, going to the beach, or taking her big dog, Maverick, on nature hikes.

\section{KIMBERLY R. FAKE}

Kimberly Fake is a research coordinator at the Lincoln Park Zoo in the Urban Wildlife Center Fake enjoys studying the effects of city environments on wildlife health. Her interests were first sparked while living in Boston, Massachusetts, where she spent her weeks working at a research lab at Massachusetts Institute of Technology and her weekends bird watching. Ultimately, she went on to Michigan State University and completed a master's thesis on the effects of diet on the immune system and disease resistance of wild birds.

\section{MASON FIDINO}

I am a quantitative ecologist at the Urban Wildlife Institute. I make tools to better understand where species live and use computers and math to better conserve wildlife.

\section{ELIZABETH W. LEHRER}

I am the Assistant Director of the Urban Wildlife Institute at Lincoln Park Zoo in Chicago, Illinois. My research interests include how animals move and behave in cities, finding solutions to human-wildlife conflict, and improving cities for humans and wildlife. I study animals from birds to skunks to bats, through observation, cameras, and by recording the sounds that they make. I am endlessly fascinated by all of the interesting things that animals do.

\section{MAUREEN H. MURRAY}

Maureen Murray is the Wildlife Disease Ecologist with the Urban Wildlife Institute at Lincoln Park Zoo. Her research focuses on the health of urban wildlife including diseases, nutrition, and stress. Urban wildlife health is important to conserve nature in cities and to prevent the spread of disease between animals and people. Maureen first became interested in urban wildlife during her Ph.D. on urban coyotes, because they have to figure out how to cross roads and find food while avoiding people. Currently, Maureen studies the interactions between rats and people in Chicago, which is fascinating even when it is gross. 